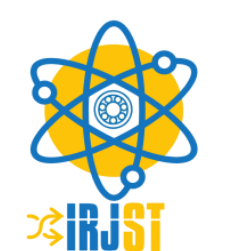

Available online at https://www.irjst.com/

International Research Journal of Science and Technology

ISSN: $2707-3955$

DOI: https://doi.org/10.46378/irjst.2020.020104

\title{
Caste Formation in India.
}

\author{
Sajitha D V $\mathbf{1}^{*}$, Ajith Kumar M P \\ ${ }^{1}$ Research scholar, School of Gandhian Thought and Development Studies, Mahatma Gandhi University Kerala, India. \\ ${ }^{2}$ Department of History, Mahatma Gandhi University Kerala, India.
}

\section{Paper Status}

Received

Accepted

Published
Nov 2020

Nov 2020

Dec 2020

\author{
Key Words \\ Caste in Bhagavat Gita \\ Caste Interpretation Of Manu \\ Caste $n$ Vedic \\ Later Vedic Period \\ Modern India
}

\begin{abstract}
The purpose of this study is to look at how caste formation, a structural feature of Indian society and the changes that have taken place in caste formations over time, are used by caste in today's society. The structure of Indian society is based on the caste system. But the caste system was only a product of the upper caste Brahmins of India. In fact, the upper castes enslaved the lower castes only for economic purposes. For that, they used caste as the first extreme. According to historians, the caste system in India was only part of a division of labor and was never caste-based. Because there is no mention in Manusmriti, Bhagavat Gita, Vedic and Later-Vedic literatues about a caste society that separates man from man on the basis of caste. That is why our social reformers proclaimed that caste evils should be eradicated from the society and they worked hard for it and succeeded to some extent. Thus, Independent India was able to build a casteless society as a result of the work of social reformers. But after independence we were able to see a caste politics. What we see today is that every political party is using caste as a tool for their vote bank during elections to consolidate their power. Therefore, caste politics is one of the major challenges facing India.
\end{abstract}

Copyright (C) 2020: Sajitha D V, Ajith Kumar M P. This is an open-access distribution, and reproduction in any medium provided Access article distributed under the Creative Commons Attribution License the original work is properly cited License, which permits unrestricted use.

Citation: Sajitha D V, Ajith Kumar M P. "Caste Formation in India". International Research Journal of Science and Technology, 2 (1), 323-326, 2020.

\section{Introduction}

Social formation in India is determined on the basis of caste system. Therefore, the zeal of the caste system was rampant in Indian society. In fact, Indian casteism was only a consequence of the selfish interests of the elite groups. But historians have put forward many theories about the origin of the caste system. Let us evaluate what they are. A section of historians claim that the caste system in India came into being with the arrival of the Aryans. Swami Dayananda Saraswati puts forwarded the theory in order to validate their theory. According to Aryan theory, outsiders are Brahmins and the indigenous of India are lower caste.

\footnotetext{
* Corresponding Author: Sajitha D V

Research scholar, School of Gandhian Thought and Development

Studies, Mahatma Gandhi University Kerala, India.

Email: sajitha.divakaran4@gmail.com
}

However, there are differing opinions among historians as to the role of caste in social formation during the Vedic period.

That is to say, what existed in the caste society at that time was based on the trade and work of the people. Initially, certain social groups traditionally engaged in certain occupations, but this was not a caste-based social formation. But gradually some social groups emerged on the basis of the occupation. For example, a merchant named Panis mentions that trade was established in the Mediterranean region, the main emporium in Europe. Therefore, historian Kalyan Raman argues that the founders of the Polynesian trade in Africa were the Panis of India. This was followed by the emergence of large groups such as Vaniks, Baniya and Vaniya which traded in India. Social formation at that time was based on the work that people were engaged in. In the Rig Veda, it is said that people belonging to the same family took up higher 
and lower jobs. For example, Gopala, Gokula and Vraja, herdsmen were also involved in agriculture. Similarly, the Kshatriyas were engaged in border protection but were also engaged in various jobs. Another example is that Lord Krishna was born into a cowherd community but later took over the rule of Madurai and became the king of Dwaraka. Likewise, Vyas, the son of fisherman, and his grandsons Dhritarashtra and Duryodhana later inherited the Kurukshetra Empire. In addition, Guhak became the king of Sringivera kingdom, is mentioned in the Ramayana. Another reference is to the Ekalavya's skill in archery, but Brahmin Drona teacher denied education to Ekalavya only because of his innate love for his beloved student Arjuna. From such incidents we can see that casteism was not strong in the early days. Due to this, kshetriyas also acquired spiritual knowledge during the Vedic period. Vyasan, the son of a fisherman, compiled the Vedas and wrote the epics Ramayana and Mahabharata. It is clear, therefore, that caste was not a barrier to learning at that time.

\section{Caste Interpretation of Manu}

Manusmriti is the first law book in India and its author is Manu. He categorizes people into four varnas (races) namely Brahmin, Kshetriya, Vaishya and Sudra. He also refers to the fifth color, mixed caste or Chandalas. Moreover, Brahmins should study and teach the Vedas and pass it on to others in a way that is good for the society as a whole. In his opinion God is for every person each job is assigned and they claim that they have to do it according to their ancetry.

\section{Caste in Bhagavat Gita}

In the Gita, color is compared to Karma. Gita also states that they must be faithful to the deeds given to them according to their past activities. Parasuraman was born a Brahmin but later practiced archery and is said to have destroyed the Kshatriyas. Here in the Gita, Lord Krishna comments that social life took the form of agriculture and animal husbandry and later evolved into higher political thoughts and lives. What is clear from this is that there was no caste in the Vedic period. Because in the 9th volume of the Rig Veda, a family member claims that I am a peot, my father is a doctor and my mother is a grinder. Of course, it is clear that in the past, people were engaged in various occupations and never deviated from the caste system.

\section{Caste in Vedic and Later Vedic Period}

Similarly, the Vedas and the Vedic literatures, the Smriti and the Upanishads, refer only to the division of labor and society, where no caste was given prominence. But over time, people have moved on from one job to another. Casteism was not strong in South India. The Chera, Chola and Pandya, who were the descentants of the lower caste, later established dynasties. During the Sangham period, Sudras and
Brahmins were engaged in agriculture. Evidence of this is that Manu and Yanjyavalkya mentions about the anuloma and pratiloma marriages.

But according to some historians, the caste system of the Vedic period later gave way to new religions. These are examples of Buddhist literatures Mahavamsa and Mahavamsahatika claiming Mauryan kings to be Buddhists Jainists believers. In the light of Mauryan literature, a lower caste could have become a sage or a scholar. Moreover, in Kautilya's Arthasastra, the lower castes and the upper castes mentioned a punishment. Adi Shankara then declared in his Advaita doctrine that "there is no difference between man and man and that all are one". He also declared that all human beings are symbols God. He also stated that in his opinion color is but dharma. Adi Shankara thus reclaimed the caste system in our society. After the Mughal period, a casteless society emerged and the devotional movement gained prominence. Religious reform movements began in Maharashtra in the 13th century. Namadev and Tukkaram, many lower caste teachers, rose in the society. Following this, scholars from the upper castes, such as Jnaneswar and Ekanath rejected the notion of education for Brahmins only. By the 16th century, Muslim rule was established in the Deccan and northern India. But then one day the people in India is practicing casteism in a very threatening way.

\section{Caste in Modern India}

In the 19th century, many social reformers in India worked to eradicate castiesm. Swami Dayanda Saraswati, Swami Viveknanada, Rajaram Mohan Roy, Sri Narayana Guru, Vaikunda Swamikal, Atmaram Pandurang, Joti Rao Phule, Ayyankali and so on They challenged the immoralities of the society and educated the common people. Besides, Vivekananad and B R Ambedkar were important figures and they worked for the eradication of caste evils from Indian society.Thus our social reformers eradicated caste evils from Indian society. But the political parties that came to power in the 21 st century after the monarchs are trying to remove the social reformers and bring back caste evils. Politicians today use caste in a different way, that is, they use a system to get caste votes to their party during election.

\section{Conclusion}

Although there are many theories about the origin of caste in India, there is still no clear understanding of caste among historians. In the early days, caste was used by the upper castes of the society to maintain their interests and to enslave the lower castes. There I no historical record that says caste should be practiced. But later our social reformers were able to eradicate to some extent the nefarious practices that separate man from man as part of various social reforms in the 
society but caste zeal is being used by the present society to maintain their selfish interests. This is validated by the fact that our political parties are using caste as a tool to get votes for their party and especially to maintain their power during elections. As a result, our Indian politics is being maligned by caste. Therefore, we can build a Secular, Socialist, Democratic India only if such caste thinking changes.

\section{Acknowledgement}

At the outset I express my sincere gratitude to my beloved Prof: M P Ajith Kumar, who sincerely guided as in my article with great patience. Sincere thanks to our Director, prof: M.H.Iliyas for extending all academic support throughout my study. I am extremely grateful to all my faculty members of History Department. I also thank the staff members of the library for providing me with the study materials as and when needed. I also thank my friends who helped directly or indirectly in my studies. I am extremely grateful to my parents and my husband for all support and encouragement providing throughout my studies. I thank Almighty God for support to this work.

\section{Bibliography}

[1]. A. Sreedhara Menon, Triumph and tragedy in Travancore, annals of sirs' sixteen years in dept. Press, Kottayam, p.61.

[2]. A. Sridhara Menon, a Survey of Kerala history.sanker road sankaramangalam Trivandrum 10th June 1967,309.

[3]. Anshu Malhotra, Genter caste and religion identities restructuring class in colonial Punjab, Oxford University press New Delhi 2002, p.86.

[4]. Bandyopaddhyay Sekhar, Caste, culture and hegemony social domination in colonial Bengal.sage publication newdelhi thousand oaks London 2004, p.43.

[5]. Bayly Susan, Caste, society and politics in India from the eighteenth century to the medium age, Cambridge University press Cambridge 1991, p.97.

[6]. Burton Stein, Essays on south India, vikas publishing house private limited, p.53.

[7]. Cherian.P.J, Perspectives on Kerala history, the second millennium state editer, kerala gazetter's vol: 11 part11 dept. 1999, p. 405.

[8]. David.N.Lorenzen, Religious movements in south Asia 600-1800.debates in Indian history and society, Oxford University press New Delhi 2004, p.89.
[9]. Della Donatella and mariodian, Social movement's introduction, Blackwell publishing oxford 2006, p.201.

[10]. Dipanker Gupta, Caste in question: identity or hierarchy: newdelhi sage 2004, p.36.

[11]. Dipanker Gupta, Interrogating caste understanding hierarchy and difference in Indian society, penquin books New Delhi 2000,332.

[12]. Guru Narayana, The social philosopher of kerala by sathya bai sivadas, prabhakara rao published by havens books, pp.43-44.

[13]. Gurukkal Rajan \& m.r. raghava varier, Cultural heritage of kerala,second edition 1996.first published.january 1978.ananda book depot "action lodge 38 " mc Nicolas chetput,madras-600 031 pp,421-23.

[14]. Gurukkal Rajan \& M.R.Raghava Varier, Cultural history of kerala vol: 1 department of cultural publications government of Kerala 1999, p.96.

[15]. Hanlon O'Rosalind, Caste, conflict and ideology,mahatma jotirao phule and low caste protest in nineteenth century western india Cambridge university press London 1985,pp.67-69.

[16]. Jaiswal Survira, Caste -origin, function and diamensions of change, manohar publishers and distributers New Delhi 1998, p.87.

[17]. Jonathan Michie, Encyclopedia of social sciences. Chicago fitzery deaborn publishersp.507.

[18]. K.Saradamoni, Kerala: society and politics, institute of management in government Trivandrum1991, p.76.

[19]. Klass Morton, Caste, the emergence of a south Asian social system, institute for the study of human issues Philadelphia 1980, pp376-78.

[20]. Neil J Smelses haal b baltes, International encyclopedia of the social and behavioural sciences volume 16.2001, p.812.

[21]. Sudari T.K, Caste and and agrarian structure a study of chigleput district, tamilnadu, south India, cds Trivandrum 1994, p.265.

[22]. Ursula Sharma, Caste, concepts in the social sciences, viva books private limited, newdelhi2002, 365. 


\section{E- Journals}

[1]. Chris Wilson and Pallikada Vathsaseendran, a paradox within a paradox: scheduled caste fertility in kerala published by economic and political weekly.stable.

url:http://www.jstor.org/stable /4416878.

[2]. Davidkent "peri://www.athiest community .org/stable/library/articles/read.php.id =710 retrieved 06-21-2007.yar aca.http.

[3]. Dipanker gupta, Caste and politics: identity over system published by annual reviews stable.

url://www.jstor.org/stable/25064892.

[4]. George Varghese, Globalization Trumans and new social imaginary.

[5]. Election guide, Election cellof malayala manorama Trivandrum 2011.

[6]. Gough, e.kathleen, Nayars: century, Kerala in Schneider, davidmurray, gough, e.kathleen.matrine al kingship university of California press.isbn.

[7]. Jeffry robin, the decline of nair dominance: society and politics in Travancore 1847-1908.sussex universitypress.

[8]. Mohindra k.s, d.narayana and haddad slim, Evidence based public health and practice, women's health in a rural community in kerala, India: do caste and socio-economic position matter.j epidemonial community health 2006 .

[9]. Mohanty manoranjan, Class, caste and genter, Sage publications newdelhi thousands oaks London 2004.

[10]. Nossiter Thomas Johnson, Keralas's identity: unity and diversity ".communism in kerala: a study in political adaptation.university of California press ISBN 9780520046672.

[11]. Sitush, Caste system in kerala, Wikipedia, the free encyclopedia (talks and contributions) 3 seconds time http://www.vivekananda.net/pdf books/from Colombo to almora.pdf.

[12]. Syamlal, Untouchables caste in India, the raigar movement (1940-2004), rawat publications newdelhi 2006.

\section{Internet Sources}

[1]. Directory 2010-2011 the free encyclopedia en.wikipedia.org.
[2]. Directory 2011 Diocese of Alleppey kerala, India, bishop house p b no: 4804.

[3]. http://www.vivekananda.net/pdf books/from Colombo to almora.pdf.

[4]. Wikipedia, the free encyclopedia en.wikipedia.org/wiki/p.parameswara. 